\title{
Characterization of modified cassava flour (mocaf)-based biscuits substituted with soybean flour at varying concentrations and particle sizes
}

\author{
*Ratnawati, L., Desnilasari, D., Kumalasari, R. and Surahman, D.N. \\ Research Center for Appropriate Technology JL KS Tubun No 5 Subang 41213 West Java- Indonesia
}

\begin{abstract}
Article history:
Received: 12 August 2019

Received in revised form: 4 December 2019

Accepted: 14 December 2019

Available Online: 4 January 2020
\end{abstract}

Keywords:

Particle size,

Soybean flour,

Mocaf-based biscuits

DOI:

https://doi.org/10.26656/fr.2017.4(3).282

\section{Introduction}

In general, complementary foods on the market are biscuits and instant porridge. Biscuits are small baked products made principally from flour, sugar, and fat (Manley, 1998) and have a long shelf life due to their low moisture contents. Although wheat flour is most commonly used for making biscuits, it is not produced in Indonesia, and alternative ingredients such as cassava flour are used to make biscuits as a complementary food. Modified cassava flour (mocaf) is a fermentation product of cassava; among many agricultural commodities produced in Indonesia, cassava production reached 19,053,748 tons in 2017 (BPS, 2018). The disadvantage of mocaf is its low protein content, at $1.77 \%$ (Afifah and Ratnawati, 2017), to meet the minimum protein content requirement of $6 \%$ in complementary foods (BSN, 2005). Alternative ingredients with high protein content and production in Indonesia are needed, one of them is soybean. Soybean production in Indonesia is relatively high, with an annual production of 538,253 tons in 2017 (BPS, 2018). Moreover, the protein content of soybean flour is $40.94 \%$ (Ratnawati et al., 2019).

Particle size is considered one of the most important physical properties of powders because it affects flowability (Abu-Hardan and Hill, 2010). Specifically, small particles have higher cohesiveness, reflecting greater contact area and stronger intermolecular forces between particles (Landillon et al., 2007). Furthermore, dough rheology is influenced by particle sizes and their distributions (Moreira et al., 2014; Ahmed et al., 2016), and differences in particle sizes can be exploited to give different characteristics to food products, especially bakery products.

Previous studies have been reported on complementary foods based on wheat flour substituted with Dumbo catfish flour and soybean protein isolates (Mervina et al., 2012); soybean flour, arrowroot starch, and sweet potato flour (Zulfa and Rustanti, 2013); arrowroot starch, soybean flour, and sweet potato flour (Aini and Wirawani, 2013). In other studies, non-wheat flour-based complementary foods have been made from maize, soybeans and moringa leaves (Odinakachukwu et al., 2014); maize, millet and moringa leaves (Arise et al., 2014); millet, sorghum, pumpkin and amaranth seed flour (Simwaka et al., 2017). The use of mocaf as raw material for making complementary food is still rarely done, so this study is required to determine the characteristics of mocaf-based biscuits where soybean flours with varying particle sizes were used as substitutes at varying concentrations.

\section{Materials and methods}




\subsection{Materials}

Mocaf was obtained from UKM Harapan Jaya, Subang, West Java, Indonesia. Soybean (Glycine max) was purchased from a local market at Subang. Soybeans were washed and soaked in water at $60^{\circ} \mathrm{C}-70^{\circ} \mathrm{C}$ for 3 hrs, then dehulled and dried at $50^{\circ} \mathrm{C}$ for $12 \mathrm{hrs}$. Particle sizes of soybean flours were reduced using a disk mill and a sieve until particle sizes of 420, 250, and $177 \mu \mathrm{m}$ was achieved. Other ingredients included banana (Musa acuminata), egg yolk, powdered sugar, baking powder, unsalted butter, and lecithin.

\subsection{Preparation of composite flour}

Composite flour was made by weighing mocaf and soybean flour according to the composition in Table 1. After that, composite flour was mixed using a dry mill and then stored in polypropylene (PP) plastic bags for further analysis.

\subsection{Preparation of mocaf-based biscuits}

Biscuits were made in the Pilot Plant Bakery of the Research Center for Appropriate Technology, Indonesian Institute of Sciences, Subang, West Java, Indonesia. Biscuit formulations are shown in Table 1.

Unsalted butter, powdered sugar, egg yolk, and lecithin were mixed together using a high-speed mixer until they expanded. Banana puree and baking powder were then added and stirred to homogeneity using a lowspeed mixer. Subsequently, soybean flour and mocaf were added and mixed by hand until a smooth dough was produced. Biscuit dough was sheeted to a final thickness of $7 \mathrm{~mm}$ and baked for 10 mins in an oven at $150^{\circ} \mathrm{C}$. Biscuits were then inverted and baked for 20-30 min at $100^{\circ} \mathrm{C}$. After cooling, the biscuits were placed in polypropylene (PP) plastic bags and were stored at ambient temperature for further analysis.

\subsection{Pasting properties of composite flours}

Pasting properties of composite flours (mocaf and soybean flours) were analyzed using a Rapid Visco
Analyzer (RVA-TecMaster, Macquarie Park, Australia). Suspensions of $3.5 \mathrm{~g}(14 \% \mathrm{wb})$ of flour in $25 \mathrm{~g}$ of distilled water were stirred at $50^{\circ} \mathrm{C}(160 \mathrm{rpm})$ for $1 \mathrm{mins}$, then heated from $50^{\circ} \mathrm{C}$ to $95^{\circ} \mathrm{C}$ for over 7.5 mins and maintained at $95^{\circ} \mathrm{C}$ for 5 mins. Suspensions were then cooled from $95^{\circ} \mathrm{C}$ to $50^{\circ} \mathrm{C}$ for over $7.5 \mathrm{mins}$ and incubated at $50^{\circ} \mathrm{C}$ for 2 mins. Parameters were measured on the Visco-amylogram: peak viscosity (PV), breakdown viscosity (BV), final viscosity (FV), setback viscosity $(\mathrm{SV})$ and pasting temperature (PT).

\subsection{Evaluation of mocaf-based biscuits}

Physicochemical analysis of samples was performed to determine proximate, calorie contents, color and textural properties. Proximate analysis was performed according to the Indonesian National Standard (BSN, 1992) procedures and included determinations of moisture, ash, and crude fat contents using Soxhlet extraction. Protein of biscuit was analyzed using a DuMaster protein analyzer (DuMaster D-480, Buchi, Switzerland). Total carbohydrate content was calculated by subtracting percent moisture, ash, protein, and fat contents from 100\% (100-( $\%$ moisture $+\%$ ash $+\%$ protein $+\%$ fat)). Calorie content was calculated using the Atwater conversion factors for proteins $(4 \mathrm{kcal} / \mathrm{g}$ ), carbohydrates (4 kcal/g), and lipids ( $9 \mathrm{kcal} / \mathrm{g})$, as reported by Osborne and Voogt (1978).

Color of biscuit was measured using a Chromameter (NH310, China). All determinations were performed in three replicates. Color characteristics were recorded as $L^{*}$ values of $0-100$ representing dark to light, $a^{*}$ values representing degrees of redness to greenness, and $b^{*}$ values representing degrees of yellowness to blueness.

Textural properties was analyzed in terms of hardness and fracturability using a TA.XTPlus texture analyzer (Stable Micro System, Surrey, UK). A threepoint bending rig (type $\mathrm{HDP} / 3 \mathrm{~PB}$ ) was used to cut samples after placement on base beams that were $4 \mathrm{~cm}$ apart. Compression strengths was measured using the following conditions: test mode, compression; test speed,

Table 1. Formulations of mocaf-based biscuit doughs

\begin{tabular}{|c|c|c|c|c|c|c|c|c|c|c|}
\hline \multirow{2}{*}{ Ingredients $(\%)$} & \multicolumn{10}{|c|}{ Samples } \\
\hline & B1 & B2 & B3 & B4 & $\mathrm{B} 5$ & B6 & B7 & B8 & B9 & B10 \\
\hline Mocaf flour & 50 & 40 & 35 & 30 & 40 & 35 & 30 & 40 & 35 & 30 \\
\hline Soybean flour & - & 10 & 15 & 20 & 10 & 15 & 20 & 10 & 15 & 20 \\
\hline Egg yolk & 10 & 10 & 10 & 10 & 10 & 10 & 10 & 10 & 10 & 10 \\
\hline Powder sugar & 14 & 14 & 14 & 14 & 14 & 14 & 14 & 14 & 14 & 14 \\
\hline Banana puree & 14 & 14 & 14 & 14 & 14 & 14 & 14 & 14 & 14 & 14 \\
\hline Unsalted butter & 10 & 10 & 10 & 10 & 10 & 10 & 10 & 10 & 10 & 10 \\
\hline Lecithin & 1 & 1 & 1 & 1 & 1 & 1 & 1 & 1 & 1 & 1 \\
\hline Baking powder & 1 & 1 & 1 & 1 & 1 & 1 & 1 & 1 & 1 & 1 \\
\hline
\end{tabular}

Samples B2-B4 were made using flour with a particle size of $420 \mu \mathrm{m}$, samples B5-B7 were made using flour with a particle size of $250 \mu \mathrm{m}$, and samples B8-B10 were made using flour with a particle size of $177 \mu \mathrm{m}$. 
$3 \mathrm{~mm} / \mathrm{s}$; target mode distance; distance, $4 \mathrm{~mm}$. Peak forces (gf) and mean distances at breakage (mm) were recorded.

Microstructures of biscuit was analyzed using a Scanning Electron Microscope (SEM, Hitachi SU3500). Prior to SEM analysis, samples were placed on SEM holders and coated with gold under vacuum conditions. Sample images were taken at $2500 \times$ magnification with an accelerating voltage of $10 \mathrm{kV}$ (Blaszczak et al., 2004).

\subsection{Statistical analysis}

Data in tables are presented as averages from triplicate analysis. Significant differences in multiple comparisons were identified using analysis of variance (ANOVA), followed by Duncan tests for significance at $5 \%$.

\section{Results and discussion}

\subsection{Pasting properties}

Pasting properties of mocaf and composite flours (mocaf-soybean flours) were determined using RVA (Table 2). In this study, mocaf (B1) had the highest peak, breakdown, and final viscosity, but the pasting temperature for mocaf was lower than that of composite flours containing soybean flour.

The peak viscosity of B1 was significantly different $(p<0.05)$ from that of composite flour. The peak viscosity of composite flour tended to decrease with increasing soybean flour concentration. It is due to the peak viscosity of soybean flour $(19.17 \mathrm{cP})$ lower than mocaf $(4,755 \mathrm{cP})$, so that the composite is made the peak viscosity will decrease (Afifah and Ratnawati, 2017; Ratnawati et al., 2019). The addition of soybean flour in composite flours led to increased protein and fat contents. Accordingly, the protein and fat can inhibit interactions between starch granules and limit the swelling of starch, leading to changes in viscosity ( $\mathrm{Du}$ et al., 2013; Hamid et al., 2015). The results in this study similar with a previous study were conducted by Julianti et al. (2017), that showed the addition of soybean flour in composite flour consist of sweet potato flour and maize starch can decrease the peak viscosity of these blends. Furthermore, the addition of soybean flour with fine particles $(177 \mu \mathrm{m})$ caused the greater peak viscosity than the addition of soybean flour with coarse particles $(420 \mu \mathrm{m})$. This result in line with the previous study was conducted by Ahmed et al. (2015), the peak viscosity increased in very fine particles of water chestnut flour $(1,172$ to $1,218 \mathrm{BU})$.

According to Adebowale et al. (2008), high breakdown viscosity is associated with increased susceptibility of flour to withstand heating and shear stress during cooking. The breakdown viscosity of B1 differed significantly $(\mathrm{p}<0.05)$ from those of B2, B3, B4, $\mathrm{B} 7$, and B10. The increasing level of soybean flour in composite flour can be decreased the breakdown viscosity. This relates to the fiber content of composite flour. Ratnawati et al. (2019) showed that the dietary fiber of composite flour substituted by $40 \%$ soybean flour $(18.53 \%)$ higher than the dietary fiber of mocaf (9.58\%). The hydrophilic group in the fiber will form hydrogen bonds with water thereby reducing the amount of water that can be absorbed by the starch granules (Julianti et al., 2017).

The final viscosity of B1 was significantly different $(p<0.05)$ from other samples, it tended to decrease with increasing soybean flour addition. Similarly, smaller particle sizes of flours were associated with decreased final viscosity. The final viscosity was decreased due to the fat contained in soybean flour which can inhibit the swelling of the starch granules (Dautant et al., 2007). The setback viscosity of B1 was not significantly different $(\mathrm{p}>0.05)$ with $\mathrm{B} 4$ and B6 samples, but significantly different $(p<0.05)$ with other composite flours. The setback viscosity also decreased with the addition of soybean flour. In the previous study was conducted by Asante et al. (2013) water chestnut flour,

Table 2. Pasting profiles of composite flours (mocaf-soybean flour)

\begin{tabular}{ccccccccccc}
\hline \multirow{2}{*}{$\begin{array}{c}\text { Pasting } \\
\text { properties }\end{array}$} & B1 & B2 & B3 & B4 & B5 & B6 & B7 & B8 & B9 & B10 \\
\hline PV, cP & $5035.17^{\mathrm{a}}$ & $2739.67^{\mathrm{b}}$ & $2020.83^{\mathrm{b}}$ & $1537.50^{\mathrm{b}}$ & $2943.33^{\mathrm{b}}$ & $2289.50^{\mathrm{b}}$ & $1795.50^{\mathrm{b}}$ & $2964.50^{\mathrm{b}}$ & $2403.33^{\mathrm{b}}$ & $1743.50^{\mathrm{b}}$ \\
$\mathrm{BV}, \mathrm{cP}$ & $1425.00^{\mathrm{a}}$ & $481.17^{\mathrm{b}}$ & $209.00^{\mathrm{b}}$ & $80.83^{\mathrm{b}}$ & $792.17^{\mathrm{ab}}$ & $713.33^{\mathrm{ab}}$ & $513.00^{\mathrm{b}}$ & $946.33^{\mathrm{ab}}$ & $858.33^{\mathrm{ab}}$ & $571.00^{\mathrm{b}}$ \\
$\mathrm{FV}, \mathrm{cP}$ & $4352.00^{\mathrm{a}}$ & $2749.83^{\mathrm{b}}$ & $2348.33^{\mathrm{b}}$ & $2016.33^{\mathrm{b}}$ & $2682.50^{\mathrm{b}}$ & $2152.50^{\mathrm{b}}$ & $1802.17^{\mathrm{b}}$ & $2558.17^{\mathrm{b}}$ & $2054.33^{\mathrm{b}}$ & $1671.33^{\mathrm{b}}$ \\
$\mathrm{SV}, \mathrm{cP}$ & $741.83^{\mathrm{a}}$ & $491.33^{\mathrm{b}}$ & $536.50^{\mathrm{b}}$ & $559.67^{\mathrm{ab}}$ & $531.33^{\mathrm{b}}$ & $576.33^{\mathrm{ab}}$ & $519.67^{\mathrm{b}}$ & $540.00^{\mathrm{b}}$ & $509.33^{\mathrm{b}}$ & $498.83^{\mathrm{b}}$ \\
PT, ${ }^{\circ} \mathrm{C}$ & $72.18^{\mathrm{a}}$ & $72.57^{\mathrm{ab}}$ & $72.82^{\mathrm{ab}}$ & $73.49^{\mathrm{b}}$ & $72.72^{\mathrm{ab}}$ & $72.71^{\mathrm{ab}}$ & $73.10^{\mathrm{ab}}$ & $72.59^{\mathrm{ab}}$ & $72.69^{\mathrm{ab}}$ & $73.14^{\mathrm{ab}}$ \\
\hline
\end{tabular}

B1, 100\% mocaf; B2, mocaf $+10 \%$ soybean flour $(420 \mu \mathrm{m})$; B3, mocaf $+15 \%$ soybean flour $(420 \mu \mathrm{m}) ; \mathrm{B} 4, \mathrm{mocaf}+20 \%$ soybean flour $(420 \mu \mathrm{m})$; B5, mocaf $+10 \%$ soybean flour $(250 \mu \mathrm{m}) ; \mathrm{B} 6$, mocaf $+15 \%$ soybean flour $(250 \mu \mathrm{m}) ; \mathrm{B} 7, \mathrm{mocaf}+20 \%$ soybean flour $(250 \mu \mathrm{m})$; B8, mocaf $+10 \%$ soybean flour $(177 \mu \mathrm{m})$; B9, mocaf $+15 \%$ soybean flour $(177 \mu \mathrm{m})$; B10, mocaf + $20 \%$ soybean flour $(177 \mu \mathrm{m})$. Values with differing superscript letters between columns differ significantly $(\mathrm{p}<0.05)$ from each other. 
Table 3. Physicochemical properties of mocaf-based biscuits

\begin{tabular}{|c|c|c|c|c|c|c|c|c|c|c|}
\hline \multirow{2}{*}{ Parameter } & \multicolumn{10}{|c|}{ Samples } \\
\hline & B1 & B2 & B3 & B4 & B5 & B6 & B7 & B8 & B9 & B10 \\
\hline Moisture, \% wb & $4.65^{\mathrm{abc}}$ & $4.22^{\mathrm{a}}$ & $6.46^{\mathrm{d}}$ & $5.96^{\mathrm{bcd}}$ & $5.93^{\text {bcd }}$ & $6.16^{\mathrm{cd}}$ & $4.98^{\mathrm{abcd}}$ & $4.47^{\mathrm{ab}}$ & $4.76^{\mathrm{abc}}$ & $5.54^{\text {abcd }}$ \\
\hline Ash, \% wb & $1.52^{\mathrm{a}}$ & $1.97^{\mathrm{c}}$ & $2.07^{\mathrm{d}}$ & $2.32^{\mathrm{e}}$ & $1.89^{\mathrm{bc}}$ & $2.10^{\mathrm{d}}$ & $2.29^{\mathrm{e}}$ & $1.86^{\mathrm{b}}$ & $2.14^{\mathrm{d}}$ & $2.31^{\mathrm{e}}$ \\
\hline Protein, $\%$ wb & $4.07^{\mathrm{a}}$ & $9.64^{\mathrm{c}}$ & $11.90^{\mathrm{e}}$ & $14.27^{\mathrm{f}}$ & $9.16^{\mathrm{b}}$ & $11.62^{\mathrm{d}}$ & $14.17^{\mathrm{e}}$ & $9.29^{\mathrm{b}}$ & $11.77^{\mathrm{de}}$ & $14.18^{\mathrm{f}}$ \\
\hline Fat, \% wb & $17.54^{\mathrm{a}}$ & $19.88^{\mathrm{b}}$ & $22.15^{\mathrm{cd}}$ & $24.20^{\mathrm{f}}$ & $21.24^{\mathrm{bc}}$ & $21.80^{\mathrm{bc}}$ & $23.28^{\mathrm{def}}$ & $21.66^{\mathrm{cd}}$ & $22.47^{\text {cde }}$ & $23.98^{\mathrm{ef}}$ \\
\hline Carbohydrate, $\%$ wb & $72.22^{\mathrm{e}}$ & $64.29^{\mathrm{d}}$ & $57.42^{\mathrm{b}}$ & $53.25^{\mathrm{a}}$ & $61.79^{c}$ & $58.31^{\mathrm{b}}$ & $55.27^{\mathrm{a}}$ & $62.71^{\mathrm{cd}}$ & $58.86^{\mathrm{b}}$ & $53.99^{\mathrm{a}}$ \\
\hline Calorie, kcal/100 g & $463.02^{\mathrm{a}}$ & $474.66^{\mathrm{b}}$ & $476.63^{b}$ & $487.88^{c}$ & $474.94^{\mathrm{b}}$ & $475.96^{\mathrm{b}}$ & $487.34^{\mathrm{c}}$ & $482.98^{\mathrm{bc}}$ & $484.77^{\mathrm{bc}}$ & $488.54^{\mathrm{c}}$ \\
\hline \multicolumn{11}{|l|}{ Color } \\
\hline $\mathrm{L}^{*}$ & $49.88^{\mathrm{bc}}$ & $50.04^{\mathrm{bc}}$ & $45.46^{\mathrm{a}}$ & $48.02^{\mathrm{b}}$ & $51.35^{\mathrm{cd}}$ & $50.15^{b c}$ & $48.97^{\mathrm{b}}$ & $55.08^{\mathrm{f}}$ & $53.62^{\mathrm{ef}}$ & $52.43^{\mathrm{de}}$ \\
\hline$a^{*}$ & $3.64^{\mathrm{a}}$ & $5.25^{\mathrm{c}}$ & $3.93^{\mathrm{a}}$ & $5.26^{\mathrm{c}}$ & $5.29^{c}$ & $5.45^{\mathrm{c}}$ & $5.73^{c}$ & $4.59^{\mathrm{b}}$ & $5.54^{\mathrm{c}}$ & $5.31^{\mathrm{c}}$ \\
\hline$b^{*}$ & $14.56^{\mathrm{a}}$ & $17.14^{\mathrm{c}}$ & $16.40^{\mathrm{b}}$ & $18.80^{\mathrm{d}}$ & $17.59^{c}$ & $18.65^{\mathrm{d}}$ & $18.63^{\mathrm{d}}$ & $17.72^{\mathrm{c}}$ & $18.44^{\mathrm{d}}$ & $18.85^{\mathrm{d}}$ \\
\hline Hardness, gf & $1242.13^{\mathrm{a}}$ & $3921.38^{\mathrm{b}}$ & $4141.14^{\mathrm{bc}}$ & $4995.42^{\mathrm{de}}$ & $3964.00^{b}$ & $4158.62^{b c}$ & $5690.87^{\mathrm{e}}$ & $4174.69^{\mathrm{bc}}$ & $4834.20^{\mathrm{cd}}$ & $5526.91^{\text {de }}$ \\
\hline Fracturability, mm & $22.04^{\mathrm{e}}$ & $22.14^{\mathrm{e}}$ & $20.68^{\mathrm{ab}}$ & $20.78^{\mathrm{abc}}$ & $20.61^{\mathrm{a}}$ & $21.08^{\mathrm{abcd}}$ & $21.66 \mathrm{~d}^{\mathrm{e}}$ & $20.64^{\mathrm{a}}$ & $21.29^{\mathrm{bcd}}$ & $21.36^{\mathrm{cd}}$ \\
\hline
\end{tabular}

B1, 100\% mocaf; B2, mocaf $+10 \%$ soybean flour $(420 \mu \mathrm{m})$; B3, mocaf $+15 \%$ soybean flour $(420 \mu \mathrm{m}) ; \mathrm{B} 4, \mathrm{mocaf}+20 \%$ soybean flour $(420 \mu \mathrm{m})$; B5, mocaf $+10 \%$ soybean flour $(250 \mu \mathrm{m})$; B6, mocaf $+15 \%$ soybean flour $(250 \mu \mathrm{m})$; B7, mocaf $+20 \%$ soybean flour $(250 \mu \mathrm{m})$; B8, mocaf $+10 \%$ soybean flour $(177 \mu \mathrm{m})$; B9, mocaf $+15 \%$ soybean flour $(177 \mu \mathrm{m})$; B10, mocaf + $20 \%$ soybean flour $(177 \mu \mathrm{m})$. Values with different superscript letters between columns are significantly $(\mathrm{p}<0.05)$ different from each other.

lower setback viscosity was related to high cooking quality in the finest fraction and the cooked starch did not retrograde or become stiff upon cooling.

There were no significant differences in pasting temperature of mocaf and composite flour (Table 2), except mocaf and B4 sample. The composite flour had higher pasting temperature than mocaf. These observations are similar to those reported by Ocheme et al. (2018), who showed that higher pasting temperatures with increasing groundnut protein concentrate (GPC) reflect higher water absorption capacity of the blends with higher GPC contents.

\subsection{Physicochemical properties}

In evaluations of physicochemical properties of biscuits (Table 3), moisture contents of samples ranged from $4.22 \%$ to $6.46 \%$. The Indonesian National Standard (BSN, 2005) tolerates a maximum of 5\% moisture in baby biscuits, and those made from the flour blends B1, B2, B7, B8, and B9 met this standard, whereas the other biscuit had higher water content.

The ash, protein, fat, and total calorie contents of the biscuit samples containing soybean flour were higher than those of the control. The ash content ranged between 1.52-2.32\%, and was within the Indonesian National Standard (BSN, 2005) those maximum content of ash i.e $3.5 \%$. This standard also regulates that the minimum content of protein in complementary food is $6 \%$. The biscuits in this study with soybean flour addition have a protein content that is in accordance with the standard. The highest protein content was found in the B4 biscuit (14.27\%), and the lowest protein content was B1 biscuit (4.07\%). Therefore, control biscuits made from mocaf not fulfill the Indonesian National Standards. The fat content of the present biscuits ranged from $17.54 \%$ to $24.20 \%$, reflecting significant contributions of soybean flour to the fat content of biscuits. Soybean flour was known to have high-fat content i.e $25.01 \%$ (Ratnawati et al., 2019). In this study, the biscuits produced not fulfilling Indonesian National Standards (BSN, 2005), it is due to the fat content exceeded $18 \%$. According to the Indonesian National Standard (BSN, 2005), calorie content of biscuits is required to contain at least $4 \mathrm{kcal} / \mathrm{g}$ or $400 \mathrm{kcal} / 100 \mathrm{~g}$. In this study, the calorie content of all samples were ranged 463.02-488.54 $\mathrm{kcal} / 100 \mathrm{~g}$, fulfilled the minimum energy content requirements.

Color parameters of food products are important because they affect consumer acceptance. The results in this study showed that the lightness values $\left(\mathrm{L}^{*}\right)$ of biscuits decreased with soybean flour contents (Table 3 ) and ranged between 45.46 and 55.08. Higher $L^{*}$ values indicate a brighter appearance of biscuits. The soybean flour substitutions increased the protein content of the present biscuits and were negatively correlated with lightness, indicating major roles of Maillard reactions in color formation (Chevallier et al., 2000). Laguna et al. (2011) suggested that proteins are subject to Maillard reactions when baked, leading to the development of brownish colors and decreased lightness values. The present color values followed a similar trend to that reported by Mieszkowska and Marzec (2016), who showed that the addition of chickpea flour to short-dough biscuits decreases $L^{*}$ values from 80 to 77.9 .

Higher concentrations of soybean flour were 
associated with decreased redness values (a*; Table 3 ), and these were inversely proportional to yellowness values $\left(b^{*}\right)$ of biscuits, which increased with concentrations of soybean flour, reflecting the yellowish color of soybean flour. Mieszkowska and Marzec (2016) similarly showed that the addition of chickpea flour to short-dough biscuits increases $b^{*}$ values from 23.9 to 28.6.

Textural properties are important qualities of biscuit products as they influence consumer acceptance. In this study, the result showed that the addition of soybean flour increased the hardness of mocaf-based biscuits at all concentrations. Biscuit fracturability also tended to decrease with increasing soybean flour content. Mocaf biscuits had hardness values of $216 \sim 358 \%$ of the control (100\% mocaf), indicating harder textures. Arun et al. (2015) previously identified dough components that affect the hardness of biscuits and showed interactions between protein, fat, carbohydrates, and starch contents. Similarly, Mieszkowska and Marzec (2016) indicated that the addition of $20 \%$ chickpea flour increases the hardness values of biscuits from 24.7 to $35.2 \mathrm{~N}$.

\subsection{Microstructure}

Microstructure analysis of biscuits using Scanning Electron Microscope (SEM) was shown in Figure 1. The images in Figure 1 indicate that soybean flour affects biscuit microstructures. In the biscuit control (B1), starch granules of mocaf were spread evenly and were round and large. In a study by Alcazar-Alay et al. (2015), the addition of cassava starch led to rounder granules with truncated shapes and larger size distributions (3-32 $\mu \mathrm{m})$. Herein, soybean flour of various particle sizes (B2-B10) formed aggregates between starch granules, and the ensuing matrixes of starch, fat, and protein granules led to harder textures of biscuits. These observations reflect

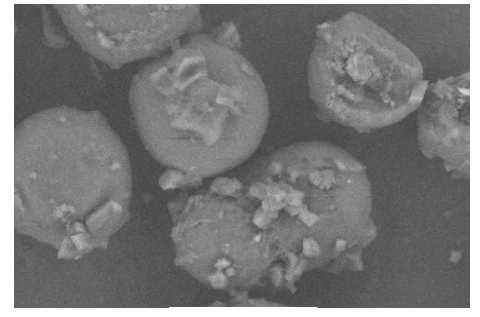

B1

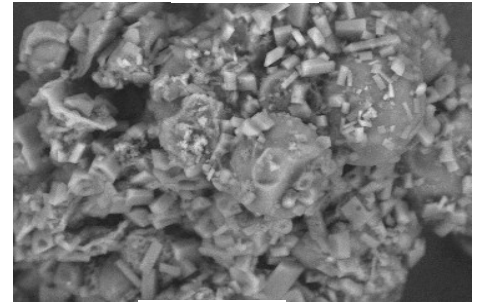

B4

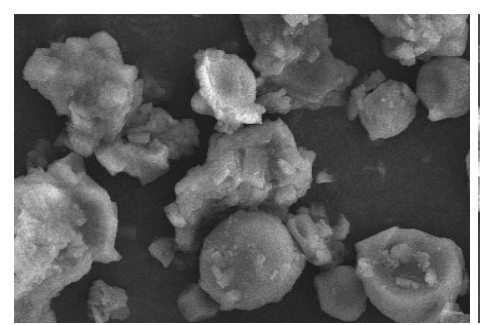

B7

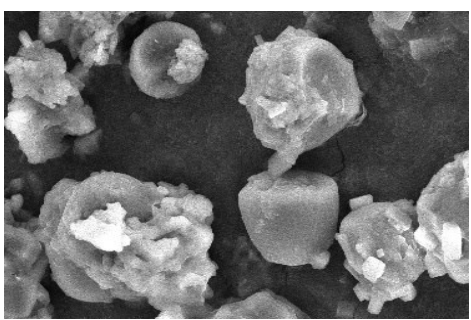

$\mathrm{B} 10$

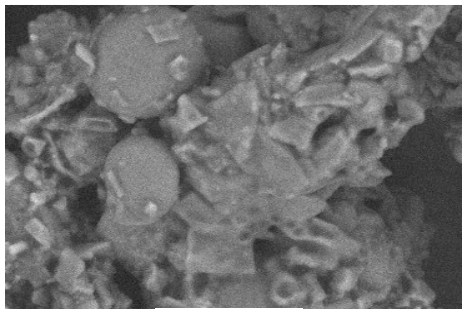

B2

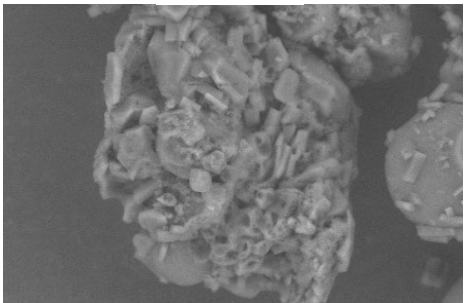

B5

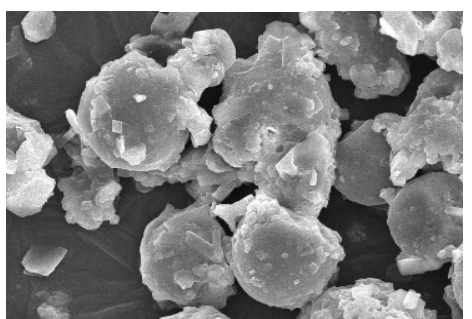

B8

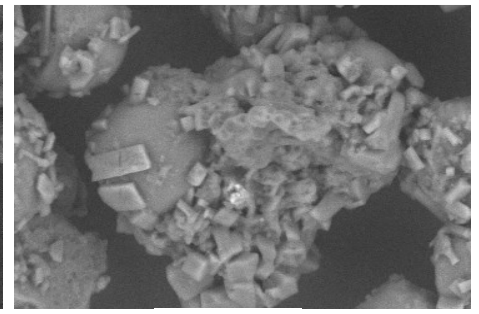

B3

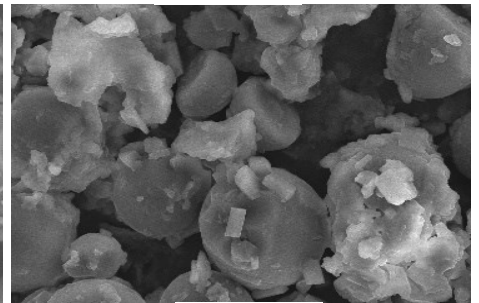

B6

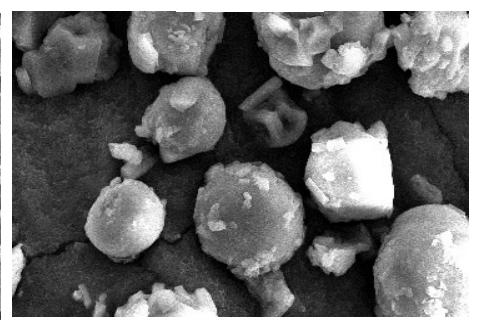

B9 
the inability of starch granules to absorb water after binding proteins and sugars, which cover the starch granules as shown in Figure 1. Chevallier et al. (2000) described biscuit structures as composite matrixes of sugar, protein aggregates, and lipids, in which intact or partially damaged starch granules are embedded. Starch granules in samples B2-B10 were also not intact, as can be seen in comparisons with the control (B1). Manley (1991) suggested that intact starch granules produce softer biscuits. Starch gelatinization also depends on the quantities and types of sugars in biscuit recipes (Filipcev et al., 2011).

\section{Conclusion}

The present analysis show that higher concentrations of soybean flour in flour composites are accompanied by increased ash, protein, and fat contents, and lead to increased hardness of the biscuits. Although particle sizes of soybean flour significantly affected the hardness, the highest protein contents were achieved with $20 \%$ soybean flour with a particle size of $420 \mu \mathrm{m}$.

\section{Conflict of Interest}

The authors declare no conflict of interest.

\section{Acknowledgments}

The authors are grateful for funding through 'Insentif Riset Sistem Inovasi Nasional (INSINAS) 2018' from the Ministry of Research, Technology, and Higher Education-Indonesia and for the use of experimental facilities at the Research Center for Appropriate Technology-Indonesian Institute of Sciences.

\section{References}

Abu-Hardan, M. and Hill, S.E. (2010). Handling properties of cereal materials in the presence of moisture and oil. Powder Technology, 198(1), 16-24. https://doi.org/10.1016/j.powtec.2009.10.002

Adebowale, A.R.A., Sanni, S.A. and Oladapo, F.O. (2008). Chemical, functional and sensory properties of instant yam-breadfruit flour. Nigerian Food Journal, 26, 2-12. https://doi.org/10.4314/ nifoj.v26i1.47417

Afifah, N. and Ratnawati, L. (2017). Quality assessment of dry noodles made from blend of mocaf flour, rice flour and corn flour. IOP Conference Series: Earth and Environmental Science, 101(1), 012021. https:// doi.org/10.1088/1755-1315/101/1/012021

Ahmed, J., Al-Jassar, S. and Thomas, L. (2015). A comparison in rheological, thermal, and structural properties between Indian Basmati and Egyptian
Giza rice flour dispersions as influenced by particle size. Food Hydrocolloids, 48, 72-83. https:// doi.org/10.1016/j.foodhyd.2015.02.012

Ahmed, J., Al-Attar, H. and Arfat, Y.A. (2016). Effect of particle size on compositional, functional, pasting and rheological properties of commercial water chestnut flour. Food Hydrocolloids, 52, 885-895. https://doi.org/10.1016/j.foodhyd.2015.08.028

Aini, N.Q. and Wirawani, Y. (2013). Contribution of complimentary food substituted with arrowroot, soybean and yellow sweet potato on the sufficiency of protein, vitamin A, calcium and zinc for infants. Journal of Nutrition College, 2(4), 458-466

Alcazar-Alay, S.C. and Meireles, M.A.A. (2015). Physicochemical properties, modifications and application of starches from different botanical sources. Journal of Food Science and Technology, $35(2), \quad 215-236 . \quad$ https://doi.org/10.1590/1678457X.6749

Arise, A.K., Arise, R.O., Sanusi MO., Esan, O.T. and Oyeyinka, S.A. (2014). Effect of Moringa oleifera flour fortification on the nutritional quality and sensory properties of weaning food. Croatian Journal of Food Science and Technology, 6(2), 6571. https://doi.org/10.17508/CJFST.2014.6.2.01

Arun, K.B., Persia, F., Aswathy, P.S., Chandran, J., Sajeev, M.S., Jayamurthy, P. and Nisha, P. (2015). Plantain peel-a potential source of antioxidant dietary fibre for developing functional cookies. Journal of Food Science and Technology, 52(10), 6355-6364. https://doi.org/10.1007/s13197-015$1727-1$

Asante, M.D., Asante, B.O., Acheampong, G.K., Offei, S.K., Gracen, V. and Adu-Dapaah, H. (2013). Farmer and consumer preferences for rice in the Ashanti region of Ghana: Implications for rice breeding in West Africa. Journal of Plant Breeding and Crop Science, 5(12), 229-238. https:// doi.org/10.5897/JPBCS13.0409

BSN (Badan Standarisasi Nasional). (1992). SNI 012891-1992. Cara uji makanan dan minuman. Jakarta: BSN.

BSN (Badan Standarisasi Nasional). (2005). SNI 017111.2-2005. Makanan Pendamping Air Susu Ibu (MP-ASI)-Bagian 2: Biskuit. Jakarta: BSN.

Blaszczak, W., Fornal, J. and Ramy, A. (2004). Effect of emulsifiers addition on dough properties, backing quality and microstructure of biscuits. Polish Journal of Food and Nutrition Sciences, 13(4), 343-348. https://doi.org/10.1007/s00217-004-0972-8

BPS (Badan Pusat Statistik). (2018). Produksi ubi kayu menurut provinsi 2014-2018. Jakarta. Retrieved on 
May 5, 2019 from Ministry of Agriculture of The Republic of Indonesia www.pertanian.go.id/home/? show $=$ page \&act $=$ view $\&$ id $=61$

BPS (Badan Pusat Statistik). (2018). Produksi kedelai menurut provinsi 2014-2018. Jakarta. Retrieved on May 5, 2019 from Ministry of Agriculture of The Republic of Indonesia www.pertanian.go.id/home/? show $=$ page $\&$ act $=$ view $\&$ id $=61$

Chevallier, S., Colonna, P., Valle, D.G. and Lourdin, D. (2000). Contribution of major ingredients during baking of biscuit dough systems. Journal of Cereal Science, 31(3), 241-252. https://doi.org/10.1006/ jcrs. 2000.0308

Du, S., Jiang, H., Yu, X. and Jane, J. (2013). Physicochemical and functional properties of whole legume flour. LWT-Food Science and Technology, 55(1), 308-313. https://doi.org/10.1016/ j.lwt.2013.06.001

Filipcev, B., Simurina, O., Bodroza-Solarov, M. and Vujakovic, M. (2011). Evaluation of physical, textural and microstructural properties of dough and honey biscuits enriched with buckwheat and rye. Chemical Industry and Chemical Engineering Quarterly, 17(3), 291-298. https://doi.org/10.2298/ CICEQ110204014F

Hamid, S., Muzaffar, S., Wani, I.A. and Masoodi, F.A. (2015). Physicochemical and functional properties of two cowpea cultivars grown in temperate Indian climate. Cogent Food and Agriculture, 1(1), 1099418.

doi.org/10.1080/23311932.2015.1099418

Julianti, E., Rusmarilin, H., Ridwansyah. and Yusraini, E. (2017). Functional and rheological properties of composite flour from sweet potato, maize soybean and xanthan gum. Journal of the Saudi Society of Agricultural Sciences, 16(2), 171-177. https:// doi.org/10.1016/j.jssas.2015.05.005

Laguna, L., Paula, V., Ana, S., Teresa, S. and Susana, M.F. (2011). Balancing texture and other sensory features in reduced fat short-dough biscuits. Journal of Texture Studies, 43(3), 235-245. https:// doi.org/10.1111/j.1745-4603.2011.00333.x

Landillon, V., Cassan, D., Morel, M. and Cuq, B. (2007). Flowability, cohesive, and granulation properties of wheat powders. Journal of Food Engineering, 86(2), 178-193.

https://doi.org/10.1016/ j.jfoodeng.2007.09.022

Manley, D. (1991). Technology of biscuits, crackers and cookies, 2nd ed., UK: Ellis Horwood Ltd.

Manley, D. (1998). Biscuit, cookie, and cracker. Manufacturing Manual 2. Cambridge: CRC Press. https://doi.org/10.1533/9781855736214
Mervina, Kusharto, C.M. and Marliyati, S.A. (2012). Biscuit formulation with catfish Dumbo (Clarias gariepinus) flour and soy (Glycine max) protein isolates as a potential food for undernourished young children. Jurnal Teknologi dan Industri Pangan, 23 (1), 1-16.

Mieszkowska, A. and Marzec, A. (2016). Effect of polydextrose and inulin on texture and consumer preference of short-dough biscuits with chickpea flour. LWT-Food Science and Technology, 73, 6066. https://doi.org/10.1016/j.lwt.2016.05.036

Moreira, R., Chenlo, F., Torres, M.D. and Rama, B. (2014). Fine particle size chestnut flour doughs rheology: Influence of additives. Journal of Food Engineering, 120, 94-99. https://doi.org/10.1016/ j.jfoodeng.2013.07.025

Ocheme, O.B., Adejiji, O.E., Chinma, C.E., Yakubu, C.M. and Ajibo, U.H. (2018). Proximate composition, functional, and pasting properties of wheat and groundnut protein concentrate flour blends. Food Science and Nutrition, 6(5), 11731178. https://doi.org/10.1002/fsn3.670

Odinakachukwu, N.I.C., Ngozi, N.N., Ngozi, I. and Aloysius N.M. (2014). Development and nutritional evaluation of infant complementary food from maize (Zea mays), soybean (Glycine max) and Moringa oleifera leaves. International Journal of Nutrition and Food Sciences, 3(4), 290-299. https:// doi.org/10.11648/j.ijnfs.20140304.19

Osborne, D.R. and Voogt, F. (1978). The Analysis of Nutrients in Foods. London: Academic Press.

Ratnawati, L., Desnilasari, D., Surahman, D.N. and Kumalasari, R. (2019). Evaluation of physicochemical, functional and pasting properties of soybean, mung bean and red kidney bean flour as ingredient in biscuit. In IOP Conference Series: Earth and Environmental Science, 251, 012026. https://doi.org/10.1088/1755-1315/251/1/012026

Simwaka, J.E., Chamba, M.V.M., Huiming, Z., Masamba, K.G. and Luo, Y. (2017). Effect of fermentation on physicochemical and antinutritional factors of complementary foods from millet, sorghum, pumpkin and amaranth seed flours. International Food Research Journal, 24(5), 18691879.

Zulfa, N.I. and Rustanti, N. (2013). Protein digestibility by in vitro and organoleptic of complementary foods substituted with soybean flour, arrowroot starch and yellow sweet potato flour. Journal of Nutrition College, 2(4), 439-446. 